\title{
The Role of Cooperative Societies in Advancing Small and Medium Scale Enterprises in Osun State, Nigeria
}

\author{
Olalekan Abiodun Adekunle ${ }^{1 *}$ \\ Timothy Olalekan Ola ${ }^{2}$ \\ Ranti Ogunrinade ${ }^{3}$ \\ Abayomi Tunde Odebunmi $^{4}$ \\ Department of Business Administration and Management ${ }^{1,2,3,4}$ \\ Osun State Polytechnic, Iree, Nigeria ${ }^{1,2,3,4}$
}

\begin{abstract}
Due to dwindling economic situation most especially in developing countries, people have resulted into self-help through cooperative societies to raise funds for starting small and medium enterprises (SMEs). It was on this premise that the study critically examined the activities of cooperative societies in Osun state in furthering SMEs advancement. The study adopted qualitative research method through in-depth exploratory design to explain 'what' and 'how' rather than mere prediction. A comparative multiple case study was used as it closely links empirical observations with existing theories to explore the effect of cooperative societies on enterprise creation and expansion and its impact on the advancement of SMEs in Osun State, Nigeria. Four cooperatives were selected and studied. Findings affirmed the significant role played by cooperative societies in advancing SMEs in Osun State. The study concludes that cooperative societies intervention in providing micro loans to members for investment purpose in the area of enterprise formation and expansion is encouraging and should be sustained to improve the prosperity of individuals in Osun State. It was recommended that the promoters of cooperative societies in the State and Nigeria must sustain and increase efforts towards advancing SMEs through the provision of financial facilities to members.
\end{abstract}

Keywords: Cooperative society, Small and Medium Enterprises, Osun State

*Corresponding author: Olalekan Abiodun Adekunle; Email: lekanadekunle77@gmail.com DOI: https://doi.org/10.37227/JIBM-2021-05-735

\section{Introduction}

The economic insufficiency and social inadequacies gave rise to emergence of various cooperative societies among professions and trades. Examples of such cooperative societies can be found among men and women in different trades and businesses. Through the formation of cooperative societies, it becomes easy for people to come together and contribute to finance their businesses (Hussain, 2014; Akinbode,\& Imhonopi, 2015). Cooperative society can be described as a form of business organization whereas body of persons with familiar passion jointly decided to establish an enterprise to advance their economic undertakings in term of manufacturing, circulation, buying and selling of commodities and offering of services for the supplying of welfare gains to the members (Effiom, 2014). 
According to Adedayo, Salau, Abdulraheem, \& Zekeri (2020) cooperatives perform an essential duty in aiding connection to capital, procurement, stockpiling and circulation of inputs and marketing of commodities, this invent jobs most especially for those living in agrarian communities and also permit less privilege people to organize for communal and economic assistance that could improve their ways of living. Specifically, cooperative societies were established to provide social, economic value and administrative support to the members. A study conducted in Shiselweni region of Swaziland confirmed mismanagement of funds by employees, ageing of members, long overdue debts by members and lack of commitment of organisers as constraints hindering the performance of cooperatives (Masuka et al., 2016).

One of the areas cooperative society has impacted is SMEs and major area of intervention has been SME financing (OECD, 2015). This is because conventional bank sources of finance are often difficult for interested entrepreneur to access. Mobilizing individual funds for promoting enterprise formation became an option for cooperative societies since it fundamentally safeguards interest of members (Bakare, \& Akinbode, 2016).Despite that Cooperatives exist to provide members with better alternative services such as regular savings, business finances, short and long term loan, mentoring, education and entrepreneurial training including buying and selling of goods at reasonable prices (Nembhard, 2014; Oluyombo, 2013), its impact on the promotion of small and medium enterprises in Nigeria has not been deeply explored. Most studies conducted on cooperative society focused on the membership development thus leaving a considerable knowledge gap regarding its impacts on the small and medium scales enterprises in developing economies.

This research is significant because its outcome will provide useful information on the roles of cooperatives in enhancing the SMES in Osun State, Nigeria. The findings will also provide relevant and fundamental information and the basis of comparison for future research in the fields of cooperative societies. In addition, it will provide a framework for the development and sustainability of the cooperatives societies in Nigeria. As a matter of fact, a research in this area is informed by the PWC MSME Survey (2020) that revealed disturbing report on the Nigerian business and entrepreneurial climate. The report supports the need for further research into areas, which can enhance the growth and development of entrepreneurship environment in Nigeria. This is more so, in view of the fact that the global pandemic impacting the world's economic trajectory has brought about gradual reversal of Nigeria's economic recovery path (Ozili, 2020; PWC MSME Survey, 2020). The COVID-19 and other economic issues also have consequent impact on the business environment. Subsequently, businesses that are able to withstand the economic headwinds are those that have built mechanisms and designed internal strategies to weather the storms that occur in the global and local economic spheres Aisen, Rahman, \& Yao, 2021; PWC MSME Survey, 2020). Therefore, study of the role played by cooperatives in advancing the SMEs is vital as it will elucidate the potential areas for improvement and provide relevant information for informed policies to invigorate financial providers, cooperative members and economic development.

However, this study critically examined the roles of cooperative societies in advancing SMEs in Osun State, Nigeria. The goal is to understand how cooperative operations contribute to the advancement and improvement of SMEs in Nigeria. This research covered four cooperative societies selected from a large sample of registered cooperative societies that works towards economic growth. The selected cases consisted of the most predominant SMEs in the state which include agriculture, fashion design, merchandising and bakers.

\section{Literature Review}

\section{Description of Cooperative Society}

A cooperative society is a distinct model of personal employment organization which has been generally used for decades as thrift management of resources. The society is described as an individual investment purchased and guarded by buyers and ran basically to bring gains to buyers. The gains are grants to customers on the basis of use not holding as related to other primary individual enterprise form. The gains received by customers are derived from the procurement or trading 
activities when buyers partner with the cooperative; these are shared based on the level of patronage (Barton, 1989). One of the functions of a cooperative society is the dual goal of social and economic support it provides to members (Adedayo et al, 2020).

In another perspective, cooperative society is a classic communal business formed by a group of individuals and managed by them. This according to Nembhard (2014) was to address market inadequacies which ordinarily other investments could not. Thus, the creation of cooperative societies was essentially to further members' interests. For instance, the savings and credit cooperative societies were introduced by foreign missionaries in most part of Africa (Mwelukilwa, 2001). The inauguration of current cooperative business in Nigeria was in the year 1935 when the authority of C. F Strickland acknowledges the report on the possibility of running cooperatives in Nigeria (Agbo \& Chidebelu, 2010). Since then, cooperative societies have grown in Nigeria and structured into three-tier system which are the primary cooperative society, secondary cooperative society, and tertiary cooperative society.

The cooperative society law in Nigeria was enacted in 1935. In 1937, the first indigenous cooperative society was registered as Gbedun Cooperate Producer Marketing Society. Thereafter, many other cooperatives were registered but in 1967, the Cooperative Federation of Nigeria (CFN) serving as the apex National body of all cooperatives with the Department of Cooperative in the Federal Ministry of Agriculture and Rural Development serving as the regulatory organ of government for cooperative societies in Nigeria. In Osun State, as at July 5, 2017, more than 24,000 cooperative societies had been registered by Osun State Government, Nigeria to boost the state economy. The Ministry of Commerce, Co-operatives and Empowerment in the State is saddled with the management of cooperative societies. The ministry act under the following mandates:

- Record, arrange and administer cooperative societies in Osun state.

- Aid access to credit through loans and empowerment programs to the inhabitants.

- Direct business exercise and every other lawful activity in the state.

- Increase the government level of income through duties, taxes and other lawful charges.

\section{Roles of Cooperatives in the Nigerian Economy}

Nigeria's economy is based on cooperatives. With the formulation and enactment of cooperative law in 1935, the colonial masters began the cooperative movement in Nigeria. During this time, Western Region cocoa producers founded marketing associations with the sole purpose of curbing middlemen's excesses and insuring the marketing of pure and unadulterated cocoa. Mr. C.F. Strickland's report on the potential of cooperatives in Nigeria was accepted by the Colonial Administration in 1934, prompting the project. Mr. E.E.G. Haig was subsequently appointed as the first Registrar of Cooperatives (Okone \& Ijere, 1986). The Cooperative Department was established in September 1935 at Moore Plantation in Ibadan, with a total workforce of one.

The Cooperative Regulation was passed the next year, in 1936, and the Cooperative Department was separated from the Department of Agriculture. The registration of Gbedun Cooperative Produce Marketing Society Ltd in 1937 marked the beginning of the first Nigerian cooperative. While it is true that the expansion of Nigerian cooperatives has been sluggish, with membership expanding from 12 in 1935 to 400 to 500 in 1949, and 450,000 in 1975, with significant increases in membership in successive years, there is still room for more and faster improvement (Okorie \& Ijere, 1986). In 2005, for example, there were 4.3 million members in 5000 Nigerian clubs. This very fact has gone deep into helping greatly to rekindle more interest in the study of cooperatives since it looks as if one has to be a member of a cooperative society before one can obtain any scarce and essential commodity. From 1935 to 1952, there was one central cooperative societies' division located in the Department of Agriculture in Ibadan.

The movement extended to other parts of the country from there, thanks to cooperative registration. However, as time passed, cooperative development became a regional issue, and the Cooperative Society Division of the Federal Ministry of Labour for the Federal Territory of Lagos was founded. Farmers' cooperatives flourished in the erstwhile Western Nigeria, which erected the 
famed Cocoa House, while cooperative credit societies and unions prospered in the Eastern half, which later metamorphosed into Cooperative and Commerce Bank Nigeria Limited.

In the historic regions of the country, the establishment of cooperative societies and agricultural institutions contributed to some of the great achievements credited to the good leadership of each region between 1950 and the early 1960s (Ejeakanonu, 2007). Nigerian cooperatives are divided into two types: service and producer cooperatives. The producer cooperative's goals are to encourage the adoption of contemporary technologies and to use production to contribute to national development. Procurement, marketing and expansion services, loan disbursement, consumer products sales, and member education are all handled by service cooperatives. Agriculture, banking, credit, agro-processing, storage, and other cooperative activities have achieved significant growth. Individual members of organizations voluntarily operating in a given geographic area create service cooperatives, which are the closest to communities and are organized on a shareholder basis. Cassava farmers cooperatives at the primary level, for example, provide a collection location for the farmers' production and negotiate the per ton pricing of cassava (Frank, Ngozi \& Nkem, 2012).

\section{Small and Medium Enterprises Advancement}

Description of what makes SMEs differs across the world, however, there are common grounds. According to Udechukwu (2015), SMEs as firms are often with less than 300 employees and total assets less than US\$15 million. The United Nations Development Programme (UNDP) described firms in this category as the one employing 5 to 20 employees in the case of a small enterprise or employing 21 to 99 employees in the case of medium enterprise (UNDP, 2014). On the contrary, Organization for Economic Co-operation and Development (OECD) described SMEs as firms with fewer than 500 employees, while Central Bank of Nigeria (CBN) seems to be more detailed as the regulatory body described SMEs as enterprises with asset base (excluding land) of between N5 million and N500 million and labour force of between 11 and 300.

According to Akinbode \& Imhonopi (2015), the criteria for classifying SMEs such as number of employees, sales turnover, and capital assets, among others does not cut across countries and industries. This makes it difficult to have a global consensus on what SMEs is. In the context of this study, the description of CBN was adopted in identifying what SMEs is. Therefore, businesses in this range were investigated. This is for the purpose of placing how cooperative societies have advanced enterprises within this range. Advancing SMEs implies promoting the floating of SMEs among members of the cooperative societies. It will be appropriate to know how many members of the cooperative societies that have enjoyed the floating of SMEs with the help of cooperative societies especially in the area of financing and patronage.

\section{Cooperatives Societies and SMEs Advancement}

Extant studies like that of Wanyama (2015) suggests a nexus between cooperative societies and advancement of SMEs as the study reiterated benefits of cooperative society membership such as provision of soft loans, sharing and distribution of bonus, and backing neighbourhood facilities and services such as health clinics and schools. Cooperative societies have been found to aid new development in the market by addressing the market irregularities (Deller, Hoyt, Hueth \& SundaramStukel, 2009). According to Effiom (2014) cooperative society has significance impacts on national development as they are not only accomplishing developmental activities such as in agriculture, transportation and credit creation, but also serve as a catalyst for poverty reduction through the economic and social progress of their members and employees. More so, cooperative societies and their members pay taxes, and they are good citizens by giving donations to their communities, paying their employees fairly, and using sustainable practices (Nembhard, 2014). 


\section{Challenges by the faced Cooperative Societies in Nigeria}

Cooperatives can be found in every corner of the world. Cooperatives confront one or more challenges, Nigeria inclusive. Anyanwuocha (2011) listed five significant issues for cooperative societies. Difficulty in finding an experienced person to manage the firm, insufficient money in the cooperative organization, fraud and misappropriation of funds by unscrupulous leaders, abuse of funds for political objectives, and cooperative profits are not subject to taxation are some of these issues. Also, Akanle, Omotara, Busari (2014) asserted that competition from other financial institutions is one of the challenges faced by cooperative societies in Nigeria, since there are many alternatives to financing the business, other financial sectors compete with cooperative society by offering similar or additional benefits. Other challenges according to Gbadeyan (2001) are loan defaulting (loan delinquency), irregularity in the repayment of loan, poor saving culture of some members because of the soften regulation in some cooperative organizations, few members take advantage of it by making unequal savings, which may lead to insolvency. Some cooperative societies choose the management board based on the number of shares and total saving without considering the expertise and level of education, and lack of good management and cooperatives capacity building have been identified as the challenges encountered by the cooperative societies in Nigeria (Akanle, Omotara, Busari, 2014).

\section{Overview of the Small and Medium Scale Enterprises in Nigeria}

Small and Medium Enterprises (SMEs) in many emerging markets and developing countries Nigeria inclusive do not have access to financing (Beck, Demirguc-Kunt, \& Maksimovic, 2004; Berger \& Udell, 2006; OECD, 2006). This is especially worrisome in the sense that SMEs account for a large portion of the labour force, a large portion of enterprises and also a large portion of national income (Beck, Demirguc-Kunt, \& Maksimovic, 2004; Berger \& Udell, 2006; OECD, 2006). Moreover, a sizeable portion of the population already earn their living in micro or small and medium enterprises, often earning poor wages, most especially in low income developing countries (OECD, 2006). Ayyagari, Beck and Demirguc-Kunt (2003) reported that SMES and informal enterprises in low income countries, account for over 60 per cent of Gross Domestic Product (GDP) and 70 per cent of total employment. In Nigeria, SMEs when combined with micro enterprises contributed 46.54 percent to GDP in Nominal terms. A total of 32, 414, 884 persons were employed by the micro enterprises sector (SMEDAN/NBS, 2012). While a total of 39,478 persons were employed in small and medium enterprises, representing 22,139 males (56.08\%) and 17,339 females (43.92\%) (SMEDAN/NBS, 2012).

In the case of Nigeria, studies (OECD, 2006; World Bank, 2009) have shown that if environmental challenges are addressed, the SME sector could be made more robust, thereby contributing to poverty alleviation, employment generation and economic growth. Ihua (2009) also suggested that the SMEs in Nigeria are the catalysts for economic growth and development as well as the backbone of the Nation. This notwithstanding, a World Bank study (2009) has shown that low access to financing is the next most important constraint, for Nigeria SMEs after electricity shortage. Thus, a crucial element in the efforts to reduce poverty and generate employment opportunities in the country rests on the capacity of SMEs to have unhindered access to external finance. In recognition of the role of SMEs in economic growth and development, coupled with the importance of finance to stimulate the sector, the succeeding governments in Nigeria over the years have come up with the intervention programmes leading to, the establishment of several micro credit institutions. Such micro credit institutions include the Nigeria Bank of Commerce and Industry (NBCI), Nigeria Economic Reconstruction Fund (NERFUND), People's Bank of Nigeria (PBN), Community Bank (CB), Nigerian Export and Import Bank (NEXIM) and Micro-finance Bank. In addition to the establishment of the finance institutions, the government also liberalized the banking sector (Mambula, 2002). However, some of these institutions were not sustained because they were products of political regimes and went into extinction as soon as the regimes were out of power, as a result of fund starvation and neglects, hence effective development of SME sector became constrained. 
Small and Medium Enterprises Development Agency (SMEDAN) was established as an apex institution to arrest these shortcomings. As an agency it was saddled with the statutory responsibility of facilitating the creation, resuscitation and stimulation of the growth and development of the Micro, Small and Medium Enterprises (MSMEs) sector of the Nigerian economy. The government, despite the failure of past efforts to stimulate the SMEs sectors, came up with intervention programmes, which made access to finance easy (SMEDAN/NBS, 2012).

\section{Research Methodology}

This study adopted qualitative research approach to possibly find in-depth information. This approach made use of both case study and interview to generate data. A case study approach permits a subject to be researched with maximum information making use of small units of contributors (McLeod, 2008).Selection of cases involves the strategy that is crucial to the entire research study (Ghauri, 2004). The selected cases offer tangible intuition into the duties of the cooperative societies in the communities where they are situated and thereby provided an adequate insight about its impact on the advancement of SMEs. Four cooperative societies in Osun State, Nigeria formed the cases. The four cooperative societies were chosen from a large sample of registered cooperative societies in the State that works towards economic growth. The selected cases consisted of agriculture, fashion design, merchandising and bakery.

For the interview, major stakeholders such as the chief executive officers, managers, members, and owners of small-scale businesses in the selected cooperative societies to establish its contribution to the promotion of small-scale enterprises. Summary of the chosen SMEs are captured in Table 1:

Table 1: Summary of Selected SMEs in Osun state, Nigeria

\begin{tabular}{|c|c|l|l|l|l|}
\hline S/N & Name & \multicolumn{1}{|c|}{ Industry } & \multicolumn{1}{|c|}{ Duties } & Location & Members \\
\hline 1 & A & $\begin{array}{l}\text { Agriculture/ } \\
\text { Agribusiness }\end{array}$ & $\begin{array}{l}\text { Farming and } \\
\text { produce buying }\end{array}$ & $\begin{array}{l}\text { Rural } \\
\text { Community/Urba } \\
\text { n. Iragbiji. }\end{array}$ & 77 \\
\hline 2 & B & Fashion Design & $\begin{array}{l}\text { Sales of clothes } \\
\text { materials and } \\
\text { tailoring services }\end{array}$ & Urban. Ikirun. & 85 \\
\hline 3 & C & Merchandising & $\begin{array}{l}\text { Engages in } \\
\text { buying and } \\
\text { selling of } \\
\text { household } \\
\text { varieties }\end{array}$ & Urban. Osogbo. & 75 \\
\hline 4 & D & Bakery & $\begin{array}{l}\text { Production of of } \\
\text { breads, cakes, } \\
\text { and pastries }\end{array}$ & $\begin{array}{l}\text { Rural } \\
\text { Community. Iba }\end{array}$ \\
\hline
\end{tabular}

Therefore, non-probability sampling technique was adopted. Specifically, convenience sampling was adopted which according to Castillo (2009), it is a non-probability sampling technique in which selection of subjects are based on convenience, availability and closeness to the researcher.

Data were extracted from available records of the selected SMEs, Osun State cooperative society and through the interviews conducted with major stakeholders in the selected cooperative societies. Items on the interview guide were shared with interviewees ahead of the exercise. With agreement to conduct the interview under anonymous names for the four cooperative societies which were designated as (A, B, C, D) and respondents designated with positions occupied in the entity. The interviews were conducted between November, 2020 and early January 2021. It was conducted in English language. The interview took about 20 minutes per interviewee and tape recorded and interpreted verbatim. 


\section{Results and Analysis}

\section{CASE A: Agribusiness Cooperative Society}

The agribusiness cooperative society was founded in Osun State in the year 1979. The management team comprises of five experts in the field of farming while the members are also practicing farmers. The organization officially registered in 2001 with Corporate Affairs Commission of Nigeria to enable it to perform formally. The objective was to assist members financially and to exchange ideas on the agribusiness profession. The purpose of forming the association was to identify individual business challenges and to protect their collective interests.

"Due to consistent growth in members' financial contribution, the cooperatives society have been funding and supporting members' business ideas which have led to the establishment of many SMEs owned by members." Cooperative Manager

\section{CASE B: Fashion and Designing Cooperative Society}

The fashion and designing cooperative society was officially launched in the year 2004 in Oshogbo, Osun State. The firm was among the popular business in the community and mostly practiced by females. The cooperative society was formed to share professional knowledge, develop innovative ideas, and grant support for individual member.

"The cooperative society aids the spread of many small and medium scales businesses by providing mentoring and seed capital for venture creation and development." Manager

\section{CASE C: Merchandising}

This is a petty trading cooperative society established informally by female entrepreneurs in the past years but recently registered officially to benefit from State Government aids. The objective was to control the sales, monitoring of members' business performance, supervision of markets and protection of individual member interest. They engage in daily money contribution to render financial assistance among members.

"I have expanded my petty businesses from the financial loans have taken over time from the cooperative society." Cooperative Member

\section{CASE D: Bakery}

The bakery cooperative society formally founded in the year 1992. The group was formed by members in bakery association. The society conducts training, work together as team to control the price and sales of their products. Most importantly, they pull resources together and thereafter grant microloans to members to boost their investments.

"As a trade-based cooperative, members have expanded and open new business operations in bakery from the financial loans offered by the society." Cooperative Member

\section{Case Analysis and Interpretation of Findings}

After examining the four cooperative societies activities independently using detailed case analysis, the contrast and similarities among the four cases were examined and presented in a structured manner.

\section{Cross-Case Analysis and Interpretation of Findings}

After examined the four cooperative society activities separately through in-depth case analyses, the similarities, and differences between these four cases were examined and presented in a structured manner. An overview of the identified elements is given in the Table 2 below: 
Table 2: Analyses of the cases

\begin{tabular}{|c|c|c|c|c|c|}
\hline \multicolumn{2}{|c|}{ Object Of The Study } & Case A: Agribusiness & $\begin{array}{c}\text { Case B: Fashion \& } \\
\text { Designing }\end{array}$ & $\begin{array}{c}\text { Case C: } \\
\text { Merchandising }\end{array}$ & Case D: Bakery \\
\hline \multicolumn{2}{|c|}{ Administration } & $\begin{array}{l}\text { The management team } \\
\text { was elected based on } \\
\text { their performance and } \\
\text { competency to lead the } \\
\text { organisation }\end{array}$ & $\begin{array}{l}\text { The management team } \\
\text { was elected based on } \\
\text { their performance and } \\
\text { competency to lead the } \\
\text { organisation }\end{array}$ & $\begin{array}{l}\text { The elders were } \\
\text { appointed as leaders } \\
\text { because of ages and } \\
\text { business experience. }\end{array}$ & $\begin{array}{l}\text { The founders served as } \\
\text { management team } \\
\text { since the } \\
\text { commencement of the } \\
\text { organisation. }\end{array}$ \\
\hline \multirow[t]{4}{*}{ Impact } & $\begin{array}{l}\text { Membership } \\
\text { Support }\end{array}$ & 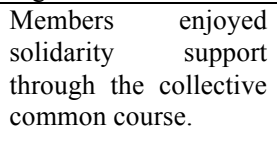 & $\begin{array}{l}\text { Members } \begin{array}{l}\text { enjoyed } \\
\text { support }\end{array} \\
\text { solidarity } \\
\text { through the collective } \\
\text { common course. }\end{array}$ & $\begin{array}{lr}\text { Members } & \text { enjoyed } \\
\text { solidarity } & \text { support } \\
\text { through } & \text { the } \\
\text { collective } & \text { common } \\
\text { course. } & \end{array}$ & $\begin{array}{l}\text { Members enjoyed } \\
\text { solidarity support } \\
\text { through the collective } \\
\text { common course }\end{array}$ \\
\hline & $\begin{array}{l}\text { Financial } \\
\text { Resources }\end{array}$ & $\begin{array}{l}\text { They pull resources } \\
\text { together through } \\
\text { members shares and } \\
\text { savings and from the } \\
\text { sales of agricultural } \\
\text { products, thereby } \\
\text { assisting members in } \\
\text { building their own } \\
\text { agri-businesses. }\end{array}$ & $\begin{array}{l}\text { They pull resources } \\
\text { together } \\
\text { monetary contributions } \\
\text { by members, thus, } \\
\text { providing microloans to } \\
\text { assist members in } \\
\text { building their own } \\
\text { businesses. }\end{array}$ & $\begin{array}{l}\text { They pull resources } \\
\text { together } \\
\text { providing } \\
\text { microloans to assist } \\
\text { members in building } \\
\text { their own } \\
\text { businesses. }\end{array}$ & $\begin{array}{l}\text { They pull resources } \\
\text { together by providing } \\
\text { microloans to assist } \\
\text { members in building } \\
\text { their own businesses. }\end{array}$ \\
\hline & $\begin{array}{l}\text { Product } \\
\text { Market and } \\
\text { Input supply }\end{array}$ & $\begin{array}{l}\text { They segment the } \\
\text { market by distributing } \\
\text { their products to } \\
\text { various communities } \\
\text { for sale. More so, they } \\
\text { engage in the } \\
\text { exportation }\end{array}$ & $\begin{array}{l}\text { They exchange ideas on } \\
\text { the provision better } \\
\text { services to customers }\end{array}$ & $\begin{array}{l}\text { They monitor and } \\
\text { control the price/sale } \\
\text { of individual } \\
\text { member's products. }\end{array}$ & $\begin{array}{l}\text { They control the price } \\
\text { of bakery products and } \\
\text { their qualities to render } \\
\text { customer service } \\
\text { satisfaction. }\end{array}$ \\
\hline & Innovation & $\begin{array}{l}\text { They share ideas on } \\
\text { new product } \\
\text { development, entering } \\
\text { new market and } \\
\text { development of new } \\
\text { structure }\end{array}$ & $\begin{array}{l}\text { Due to democratic nature } \\
\text { of cooperative, they } \\
\text { discuss and create new } \\
\text { styles and design that } \\
\text { meet customer demands. }\end{array}$ & $\begin{array}{l}\text { As the membership } \\
\text { increases, there are } \\
\text { new market creation } \\
\text { with novel structure. }\end{array}$ & $\begin{array}{l}\text { They source for new } \\
\text { source of supply for } \\
\text { product cost } \\
\text { effectiveness and } \\
\text { better service delivery } \\
\text { to the participants. }\end{array}$ \\
\hline \multirow[t]{2}{*}{ Challenges } & $\begin{array}{l}\text { Insufficient } \\
\text { funding }\end{array}$ & $\begin{array}{l}\text { Insufficient funding } \\
\text { limits the agribusiness } \\
\text { development, } \\
\text { therefore, affect the } \\
\text { product exportation } \\
\text { and economic } \\
\text { development. }\end{array}$ & $\begin{array}{l}\text { Inadequate funding limit } \\
\text { innovation in fashion } \\
\text { industry. }\end{array}$ & $\begin{array}{l}\text { Insufficient funding } \\
\text { for petty trading due } \\
\text { to non-availability of } \\
\text { collateral security to } \\
\text { borrow from banks. }\end{array}$ & $\begin{array}{l}\text { Lack of working } \\
\text { capital affect the } \\
\text { bakery business } \\
\text { development, so, } \\
\text { leading to the higher } \\
\text { price of product. }\end{array}$ \\
\hline & $\begin{array}{l}\text { Government } \\
\text { Policy }\end{array}$ & $\begin{array}{l}\text { Inappropriate } \\
\text { Government } \\
\text { cooperative } \\
\text { development policy } \\
\text { and legislation towards } \\
\text { official registration and } \\
\text { payment of tax reduce } \\
\text { the effective } \\
\text { contribution of } \\
\text { cooperative towards } \\
\text { SMEs growth. }\end{array}$ & $\begin{array}{l}\text { Government stringent } \\
\text { policy and regulation } \\
\text { affect the peoples } \\
\text { commitment } \\
\text { participate in the } \\
\text { cooperatives. }\end{array}$ & $\begin{array}{l}\text { Regular release of } \\
\text { soft loan of low } \\
\text { interest to SMEs by } \\
\text { the Government } \\
\text { through commercial } \\
\text { and microfinance } \\
\text { banks discourage } \\
\text { some people from } \\
\text { participating in the } \\
\text { cooperative. }\end{array}$ & $\begin{array}{l}\text { Regular release of soft } \\
\text { loan of low interest to } \\
\text { SMEs by the } \\
\text { Government through } \\
\text { commercial and } \\
\text { microfinance banks } \\
\text { discourage some } \\
\text { people } \\
\text { participating in the } \\
\text { cooperative. }\end{array}$ \\
\hline
\end{tabular}




\begin{tabular}{|c|c|c|c|c|c|}
\hline & & $\begin{array}{l}\text { advantage of the } \\
\text { market opportunities. }\end{array}$ & & $\begin{array}{l}\text { the market } \\
\text { opportunities }\end{array}$ & \\
\hline & $\begin{array}{l}\text { Kinship and } \\
\text { Nepotism }\end{array}$ & $\begin{array}{l}\text { Family involvement in } \\
\text { the operation of } \\
\text { cooperative brings bias } \\
\text { and favouritism in the } \\
\text { management and } \\
\text { distribution of benefits. }\end{array}$ & $\begin{array}{l}\text { There is an unfair } \\
\text { treatment of some } \\
\text { members or group based } \\
\text { on prejudice. }\end{array}$ & $\begin{array}{l}\text { Family members' } \\
\text { participation } \\
\text { disloyalty creates } \\
\text { corruption, so, it } \\
\text { hinders the } \\
\text { development. }\end{array}$ & $\begin{array}{l}\text { Family involvement in } \\
\text { the operation of } \\
\text { cooperative cause bias } \\
\text { and favouritism in the } \\
\text { management and } \\
\text { service delivery. }\end{array}$ \\
\hline & $\begin{array}{l}\text { Digital and } \\
\text { Technical } \\
\text { facility }\end{array}$ & $\begin{array}{l}\text { Lack of mechanised } \\
\text { farming affects the } \\
\text { agribusiness and no } \\
\text { conducive } \\
\text { environment for } \\
\text { corporate } \\
\text { entrepreneurial } \\
\text { developments. }\end{array}$ & $\begin{array}{l}\text { Inadequate facility and } \\
\text { lack of digitalised } \\
\text { systems have negative } \\
\text { effect on its operation, so } \\
\text { leading to delay in the } \\
\text { provision of better } \\
\text { services. }\end{array}$ & $\begin{array}{l}\text { Inadequate facility } \\
\text { and lack of } \\
\text { digitalised systems } \\
\text { have negative effect } \\
\text { on its operation, so } \\
\text { leading to delay in } \\
\text { the provision of } \\
\text { better services. }\end{array}$ & $\begin{array}{l}\text { Inadequate facility and } \\
\text { lack of digitalised } \\
\text { systems have negative } \\
\text { effect on its operation, } \\
\text { so leading to delay in } \\
\text { the provision of better } \\
\text { services. }\end{array}$ \\
\hline \multicolumn{2}{|l|}{ Accountability } & $\begin{array}{l}\text { Poor record keeping } \\
\text { and unaudited account. }\end{array}$ & $\begin{array}{l}\text { Lack of monitoring of } \\
\text { cooperative society by } \\
\text { Government agency } \\
\text { gives room for } \\
\text { corruption. }\end{array}$ & $\begin{array}{l}\text { Poor record keeping } \\
\text { and unaudited } \\
\text { account. }\end{array}$ & $\begin{array}{l}\text { There is no proper } \\
\text { record keeping with } \\
\text { lack of transparency in } \\
\text { the management of the } \\
\text { organisation. }\end{array}$ \\
\hline
\end{tabular}

\section{Discussion and implications}

The four cooperative societies have actively advanced SMEs through loan provisions to their members that are interested in either floating SMEs or expanding existing enterprise. To support this finding, Gray \& Kraenzle (2002) observed that micro loan offered by cooperatives societies have aided business growth while Oluyombo (2013) study confirmed that the financial loan of cooperative societies to members for the purpose of business has encouraged members' ownership of small businesses. It can be deduced that with strong cooperative societies and committed members who are willing and possess entrepreneurial and business education, advancing the course of SMEs growth and development will become a reality.

This analysis was based on the interview conducted with the founders of cooperative society, management team and members. The four cooperative societies were officially registered with the Osun State Government while few of their operations are not adequately following the guidelines of cooperative societies. In line with Masuku et al, (2016) findings, there should be close supervision of cooperative employees by committee members and cooperative officers to improve performances, especially in ensuring financial statements are audited.

Recently, there was an increased regulation and supervision of cooperative society in Nigeria to influence socio-economic development of the nation. Through the discussion with the chief executive officers of the selected cooperative societies, it was reported that the Government did not provide any substantial support for the development of the organization but collection of tax and tedious registration procedures. Due to lack of access to loan from banks and other financial institutions, it was found that the majority of people and small businesses in the environment participate in the cooperative to obtaining money for business creation and expansion, medicals services, purchasing food items, small farm production, paying children school fees and construction of improved houses, among others.

In response to the question on innovation, $75 \%$ of the respondents claimed that imitation is more common than innovation. One of the reasons is that most cooperatives have limited focus with narrow objective. As noted by Brat, et al. (2016), the challenge for some cooperatives is to identify innovations that are broadly relevant and to systematically roll them out. The claim by most respondents is that the inadequate application of digital technology in cooperative society system affects its innovation and entrepreneurial development. Ideally, innovation should come up from the cooperative regularly due to its democratic method of governance. As a voluntary association of individuals with common economic and social interests, cooperative societies in Africa should 
embrace the innovation and take deliberate steps to migrate their operations to digital channels (Idiong, 2020).

Furthermore, in the context of increased competition among financial institutions in Nigeria, cooperative society membership forms a major challenge. Regarding the claim of insufficient fund, it was observed that people seek easy alternatives to financing their businesses, therefore, reducing the participation in cooperative society. Most microfinance and commercial banks offering higher amount of loan with low interests and collateral free to attract small and medium scale businesses. In addition, the challenges were so many for cooperative society as an entity and among the cooperative societies' members. So, the study further implied that the administration of few cases was also based on sentiment, nepotism, and informal operation of the organization. Considering the cooperative society impacts, they have mostly the same objectives of providing microloans to members, provide adequate support to their businesses and protect the interest of individual member. To support the findings, Gray and Kraenzle (2002) observed that governance, accountability, transparency, members' participation, education, and training were considered to contribute to the performance of cooperatives society. The finding also supports the study of Oluyombo (2012) which expressed that cooperative members are more satisfied with the services received than those offered by other alternative providers.

To generate a financial resource, individual member contributes specific amount of money weekly or Monthly into the account of the organization with the objective of sharing the bulk of it as microloan to an interested member according to the guidelines. In addition, the donation, and charges received from members either on the loan or sales of an item, will reinvest and or share as dividend at the end of the cooperative year.

\section{Conclusions}

Business funding remains major hiccup for aspiring entrepreneurs in developing countries including Nigeria. One of the means that have reduced the financial hiccup is the active involvement in cooperative society. Cooperative societies have been served as means of getting things done through collaboration with other people. Through collaborative efforts, financial resource is pooled together to actualize members' intentions. It is believed that resources are more sufficient when collaborating rather than individuals' sourcing for fund for their investments. Cooperative societies intervention in providing micro loans to members for investment purpose in the area of enterprise formation and expansion is encouraging and should be sustained to improve on the prosperity of individuals, Osun State and the nation at large. Finally, among several challenges mentioned by respondents, two essential issues were raised during this study. First, participation in cooperative society is good for a nascent entrepreneur to gain desired knowledge and raise seed capital. Secondly, the protection of individual interest and democratic method of the organization. It is obvious that with microloans and business support from cooperative societies, the State of Osun has enhanced her economic growth and development because of the increasing number of businesses in what used to be known as the civil servant State. Therefore, cooperative societies need to explore this more. Also, the study encourages policies that will lead to the wider recognition and advancement of cooperative society as an alternative means of employment via business creation and entrepreneurial support. Since cooperative society is known to solve unemployment problems, there is the need for the government to implement a policy in this direction. Furthermore, it provides a set of services that complement and support the objectives of cooperative in terms of savings, sales of goods at cheaper prices to members and protection of individual member interest. Lastly, strategic alliance of related businesses can be formed on the basis of cooperative society membership of SMEs owners. This in a way would drive the growth of SMEs in the State. 


\section{Recommendations}

Based on the foregoing, adequate cooperative financing will enable the members get sufficient fund for their businesses, this can also assist in boosting existing investments. It is a known fact that no business can grow effectively without sufficient funding, when businesses grow, there will be expansions which can lead to jobs creation for the unemployed and subsequently increase in government revenue through taxes. Furthermore, there should be regular entrepreneurial and business education for cooperative society's members to ignite the spirit of investments into SMEs. The exercise should be done at interval. Lastly, the state government should provide financial support to cooperative societies that are actively involved in advancing SMEs since it will contribute to the economic prosperity of the State in the long run. Such financial support could come with zero or single digit interest rate to eliminate the challenges conventional banks give to prospective investors in SMEs

\section{Research Limitations and Directions for Future Research}

The research was designed to critically examine the roles of cooperative society on the promotion of SMEs in Nigeria by focusing on the activities of four selected active cases. The cases were selected based on their active performances and position on the list of registered cooperatives with the State Government. There are many challenges to fulfilling the suitable practical outcome discussed in the findings of this research study. When considering the practical implications from this research, it is imperative to keep in mind some underlying limitations of the research design. The use of a telephone and video call brings some bias as respondents are those that have access to the mobile network and internets who are determined to respond to the interview. The study was very demanding, time consuming and cost effective because most of the respondents failed to respond to the phone call at the specified times while few arranged for the interview at a researcher busy period. The interviews with a few respondents were not completed in a day as the researcher probe further to get an in-depth answer to the questions but rescheduled to another convenient day. The four cases selected were so few among the numbers of existing cooperative societies in the State, therefore, it cannot generalize the total outcome of the study. Case study research has been criticized due to a perception that it cannot be generalized. Multiple case studies are analogous to the replication of scientific experiments in order to determine whether a theory holds true under consistent circumstances. However, choosing good cases for extremely small samples is a challenging endeavour (Gering, 2007). The study conducted with the use of in-depth semi-structured interviews. One of the obvious issues with this type of interview is the lack of consistency in the way research questions are posed because researchers can interchange the way he or she poses them (Turner, 2010). With that in mind, the respondents may not consistently answer the same question(s) based on how they were posed by the interviewer. Future research could deal with higher number of people in order to capture the mind of larger respondents, which will guarantee the authenticity of the findings. Also, the number of cases could be increase upward from four to eight in order to have a general knowledge of the prospects and challenges confronting the societies so as to proffer a general acceptable solution to them all, widening the scope of the research will enable the researcher minimize the cost of investigation compare to when it is being done in piece meal. Being an exploratory research, it advances several opportunities for future research, both in terms of theory development and concept validation. More research will be necessary to refine and further explore the gap in the findings. 


\section{References}

Adedayo, S.J., Salau, A.A., Abdulraheem, I. \& Zekeri, A.(2020). An assessment of perceptions on entrepreneurship and self-reliance among cooperative societies in Kwara State, Nigeria. Fuoye Journal of Agriculture and Human Ecology, 3(1), 14-22.

Agbo, F. \& Chidebelu, S., (2010). Socio-economic determinants of cooperative societies' access to the services of the Nigerian Agricultural Cooperative and Rural Development Bank. Field Actions Science Reports. The Journal of Field Actions, 4, 1-12.

Aisen,A., Rahman, J. and Yao, J. (2021). IMF, International Monetary Fund, African Department. Retrieved from https://www.imf.org/en/News/Articles/2021/02/02/na020821-nigerias-roadto-recoveryon 29th May, 2021.

Akanle, O., Omotara, A.F., Busari, D.A. (2014). Cooperative Societies in the Development Discourse of Ibadan, South-western Nigeria. The Nigerian Journal of Sociology and 12 (2), 48-65.

Akinbode, J.O. \& Imhonopi, D. (2015). An assessment of micro, small and medium enterprises contribution to employment generation in Kwara State, Nigeria. Journal of Business and Social Sciences, 5(2), 103-120.

Anyanwuocha R.A.I (2011) Fundamentals of Economics (Third Edition) for SSCE, NBCE Examinations. pp 46-49.

Ayyagari, M., Beck, T., \& Demirguc-Kunt, A. (2003). Small and Medium Enterprises across the Globe: A New Database. World Bank Policy Research Working Paper No 3127.

Bakare, A.A. \& Akinbode, J.O. (2016). Development financial institutions and SMEs development in Osun State, Nigeria. Fountain University Osogbo Journal of Management, 1(2), 6-17.

Barton, D. (1989). What is a cooperative? Cooperatives in agriculture, 6, 1-20.

Beck, T., Demirguc-Kunt, A., \& Maksmovic, V. (2004). Bank competition, financing and access to credit. Journal of Money, Credit and Banking, 627-648.

Berger, A. N., \& Udell, G. (2006). A more complete framework for sme finances. Journal of Banking and Finance, 30(11), 2945-2966.

Deller, S., Hoyt, A., Hueth, B. \& Sundaram-Stukel, R. (2009). Research on the economic impact of cooperatives. University of Wisconsin Center for Cooperatives, 231, 232-333.

Effiom, R.A. (2014). Impact of cooperative societies in national development and the Nigerian economy. Global Journal of Social Sciences, 13(1), 19-29.

Ejeakanonu, E. C. O. (2007) The role of cooperative towards economic development of Anambra State: A case study of Ihiala L. G. A. Unpublished BSc Thesis, Awka: Department of CoOperative Economics and Management, Nnamdi Azikiwe University.

Gbadeyan, R.A. (2001). Problems and Prospects of Cooperative Societies in Nigeria. A case study of Kwara State. Ilorin Journal of Business and Social Sciences 7 (2 \&1) pp 105-118.

Gering, J. (2007). 'Case study research: Principles and Practices'. Cambridge, UK.

Ghauri, P. (2004). Designing and conducting case studies in international business research. Handbook of Qualitative Research Methods for International Business, 1(1), 109124

Gray, T.W. \& Kraenzle, C.A. (2002). Problems and issues facing farmer cooperatives. (No. 15022018-7837).

Hussain, M.S.(2014). The role of cooperative organizations in rural community development in Nigeria: Prospects and challenges. Academic Research International, 5(3), 176-189.

Idiong, O. (2020). 'Reading for the cloud: Embracing digital channels in cooperative societies within Africa'. Press Release. Available at: https://businessday.ng/.financialinclusion/article/reaching-for-the-cloud-embracing-digital-channels-in-cooperativesocieties-within-africa. Assessed: 21st august, 2020.

Ihua, U. B. (2009). SMEs key failure factors: A comparison between the United Kingdom and Nigeria. Journal of social Science, 18(3), 199 - 2007 
McLeod, K.D.(2008). A qualitative examination of culture shock and the influential factors affecting newly-arrived Korean students at Texas A\&M University. Texas A\&M University.

Mwelukilwa, J.(2001). The role co-operatives play in Poverty reduction in Tanzania: Paper Presented at the United Nations in observance of the International Day for the Eradication of Poverty.

Nwankwo, Frank, Ewuim, Ngozi, Asoya, Nkem (2012). Role of Cooperatives in Small and Medium Scale Enterprises (SMEs) Development in Nigeria: Challenges and the Way Forward. An International Multidisciplinary Journal, Ethiopia 6(4), Serial No. 27, October, 2012

Nembhard, J.G.(2014). The benefits and impacts of cooperatives. Grassroots Economic Organizing (GEO) Newsletter, 2.

OECD, (2006). The SME Financing Gap: Theory and Evidence. OECD Global Conference on Better Financing for Entrepreneurship and SME Growth. Brasilia.

OECD, 2015). New Approaches to SME and Entrepreneurship Financing: Broadening the Range of Instruments. Retrieved from https://www.oecd.org/cfe/smes/New-Approaches-SME-fullreport.pdf on 28th May, 2021.

Oluyombo, P.(2013). Impact of cooperative societies savings scheme in Rural finance: Some evidence from Nigeria. Economic Review-Journal of Economics and Business, 11(1), 2235.

Okorie, A. and Ijere, M.O. (1986) =Nigeria Agricultural Outlook', Nigeria Association of Agricultural Economists, Nsukka: University of Nigeria.

Ozili, P.K. (2020). COVID-19 Pandemic and Economic Crisis: The Nigerian Experience and Structural Causes. SSRN Electronic Journal, DOI: 10.2139/ssrn.3567419.

PwC's MSME Survey (2020). Building to Last Nigeria report. Retrieved from https://www.pwc.com/ng/en/assets/pdf/pwc-msme-survey-2020-final.pdf on 29th May, 2021.

SMEDAN/NBS, (2012) Survey Report on Small and Medium Enterprises in Nigeria. Abuja, Nigeria.

Wanyama, F.O.(2016). Cooperatives and the Sustainable Development Goals A contribution to the post-2015 development debate.

World Bank, (2009). Making Finance Work for Nigeria, World Bank Study. Worldbank.org/.../making_finance_work_for_nigeria.pdf .

Mambula, C. (2002). Perception of sme growth constraints in Nigeria. Journal of Small Business Management, 40(1), 58-65.

Oluyombo, O. O. (2013). 'The role of cooperative loans in rural finance: Evidence from Ogun state, Nigeria'. Journal of Cooperative Studies, 46. doi: 10: 2139/ssrn.2885366.

Onyeze, C.N., Ebue, M. I. and Ike M.U. (2014). The Problems of Financing Co-Operative Society Projects In a Competitive Economy: A Case Study of Cooperative Societies in MBANO Local Government Area of Imo State, Nigeria. Quest Journals Journal of Research in Humanities and Social Science. 2(10), pp: 11-17.

Masuka, T. A. et al (2016). 'Performance of multi-purpose cooperatives in the Shiselweni region of Swiziland'. International Journal of Sustainable Agricultural Research. 3(4). pp. 58-71. doi: 10. 18488/journal. 70/2016.3.4/70.4.58.71.

Brat, E. et al. (2016). 'Innovation priorities and practices in cooperatives: International institutes for cooperatives'. doi: 10. 13140/RG. 2. 2. /0606.10561.

Turner, D. W. (2010). 'Qualitative interview design: A practical guide for novice investigator'. The Qualitative Report. 15(3). pp. 754-760. 